\title{
A performance against the challenges in Private Industrial Security Service from Training perspective
}

\author{
V. Rangarajan,
}

\begin{abstract}
In our country's industrial growth many services have grown by leaps and bounds with advent of growing competition, de regulations, technological advancement and growing needs of FDI in different sectors. Many service sectors have grown phenomenally catering to the demanding needs of customers of different profiles. One such service is Private Industrial security services where the growth rate is approximately 30\% annually. Growth and Demand in the security services are inherently accompanied by the challenges and issues all over to different stake holders like Organisations, end users, lakhs of practicing security personnel, Govt agencies, Training organizations, HR Practitioners and Administrators. A FICCI study estimates that the private security industry's Turn over is pegged at Rs. 15,000/- crores with employment to 15 lakh people. It is expected to cross 22,000 crores with 75 lakh workforce by 2020. Yet Security industry is not properly regulated by any statutory or industry bodies in real sense to bring it on par with any other organized sector for the common good of the industry. Security needs are varied and different, given the security climate and perception in diversified industrial segments in economy. So are the equally daunting challenges, concerns, issues faced by the corporate while engaging the security personnel for safeguarding and protecting their physical and human assets. Undoubtedly this service is required in almost all walks of our lives, all through 365 days and $24 X 7$ days. Complexities apart, the security service has to come stay irrespective of industry growth rate in any given sector. Corporates are completely aware of the necessity of the service in different business conditions. Yet by nature the same complexities themselves create new challenges and perceptions within and outside this industry. The scope of the performance and accompanying challenges are far reaching to foresee the road ahead of this industry.
\end{abstract}

Index Terms: Security services, scope and importance, Training, Multi dimension challenges and issues in physical security, Causes, trends, road ahead and the ways Means to address

\section{INTRODUCTION}

An over view of Private Industrial Security Personnel from HR perspective

With advent of industrialization and globalization of industries in various sectors in the Indian context, many ancillary and support services are required by the core sectors like Manufacturing, Engineering. One such important support service gaining all round attention is Private Security Service. The peculiarity of this Security service is that the term "security service" many times supplemented by the word Watchman. The industrial Security Service has

Revised Manuscript Received on July 05, 2019.

V. Rangarajan, Ph.D Research scholar. Assistant Professor in Dpt of Management Studies at Sri Malolan College of Arts and Science, Maduranthangam, Chennai, India come off the age. From the concept of watch and ward staff, it has travelled to the present level with a lot of challenges and uncertainties where reforms are embarked by stake holders like Central Govt, State Govts and Security Industries Association .

Essentially it is a labour driven, labour intensive and labour oriented industry. Substantial degree of service is rendered by actual physical and presence of security personnel in different industrial establishments without a break round the clock. Without the human element this service is non existent. Like without a trained physician no advanced medical equipment is of any value to society.

Yet this security service is marred by many limitations --few of them are inherent and others created in absence of any structured formal education, HR Regulations, Statutory regulations. Amongst the limitations, the Training and Development take the first beating of clients sub-standard service. It is because by any standard it is evidently clear that most of Private security personnel are untrained or ill trained in absence of proper Training Infrastructure and Training personnel. Again the responsibility of Training and development lies with the HR department.

The proposed Research deals with the following concerns and critical issues connected to HR and T\&D (in other words Skilling)

1. The current Scenario of Security Training.

2. The need of Security Training.

3. The benefits of Security training.

4. The developmental aspects of Training.

5. Overall contribution of T\&D to the Industry.

6. Who gains in the above process?

7. The training methodology.

8. Training Infrastructure.

9. The role of Ex Service personnel in T\&D.

10. How HR can ignite the T\&D?

11. HR intervention in Security service.

12. How $T \& D$ contribute to meet and counter the growing security threats?

Objectives of the Conceptual Study with reference to skilling ( training) challenges faced by the Corporates

The paper focuses and highlights: 
a. An overview and Present status of the Private Industrial Security Service.

b. Understand the importance of factors affecting the performance and training.

c. Insights of different types challenges faced by different stakeholders.

e. Impact of Challenges.

f. The training scenario and the possible outcome of training to the security personnel.

\section{LITERATURE REVIEW}

1. Berrong, Stephanie (2009): India's Growing Security Industry, Security Mngt.

2. Downloaded from http://www.securitymanagement.comPage, M. and Rynn,S. (ed.) (2005) SALW and Private Security Companies in South Eastern

3. . Europe:A Cause or Effect of Insecurity? (International Alert/Saferworld/SEESAC)

4. downloaded from http://www.seesac.org/reports/psc.pdf

5. Parfomak, Paul W. (2004): Guarding America: Security Guard and U.S Critical Infrastructure Protection, Congressional Research Service Report

6. Patel, B.B. (1997) 'Contract Labour India in manufacturing, construction, plantation and forestry', Contract Labour: Looking at issues, Nine Country Cases, ILO

7. Prenzler, Tim, Earle, Karen and Sarre, Rick, (2009): Private Security in Australia: Trends and characteristics, Trends and Issues in Crime and Criminal Justice (June 2009), Australian Institute of Criminology.

8. Plight and Predicament of Security Guards Engaged by Private Security Agencies in India $\square \square$ Dr. Sanjay Upadhyaya, Fellow V.V.Giri National Labour Institute, Noida.

9. International Journal of Management Sciences, ISSN 0973-2101 Vol. 7, No.1, July 2011.

10. Research study report on Private Security services. Industry-Securing future growth by FCCI - Ernest Young.

\section{SIGNIFICANCE OF STUDY - FROM SKILLING PERSPECTIVE}

\section{WHAT IS THE MEANING OF TERM SKILL?}

An ability and capacity acquired through deliberate, systematic and sustained effort to smoothly and adaptively carry out certain complex activities or job performance involving the ideas of cognitive skills, technical skills and inter personnel skills .

\section{What does cross skilling mean?}

The term cross skilling mean improving the proficiency levels of employees so that they can carry out role/job outside their existing responsibilities.

What does Up skilling mean?
Every organization aims to hire employees who have professional training in the latest technology of his/her domain knowledge. The changes happen faster in application field before it reaches the curriculum the educational board. These changes are introduced in academic so that it is imperative that learning of new techniques takes place through learning platforms. Therefore Up skilling simply refers to learning or improving the new additional knowledge in the areas of expertise. To put in nut shell Up skilling refers to "expand the skills and abilities" usually through the training, so that the employees will be better at their job.

\section{What does Re skilling mean?}

One may have a good knowledge in the field of specilisation. But in business enterprise to be a leader, one should become a true expert in translating the business strategies into high impact solution. This calls for re learning the existing skills with a new perspective and from the various background scenario. This paves the way to sharpen the business acumen ship and analytical skills.

\section{AN ANALYSIS OF THE CURRENT TRAINING SCENARIO in Private Industrial Security SERVICES}

1. Unlike like any other business functional theories, physical security relevant to commercial enterprises is not taught in the regular academic syllabus in our country's educational sector (e.g basic knowledge of Maths, Science, Accounts, Physics, Chemistry) These areas required in order to run a smooth and sensible life in a well established society with changing acceptable norms, customs and practice

2. Security function does not find a place, in our otherwise peaceful life, for a normal individual unless there is a necessity to perform or practice as a part of occupation. (e.g Police, Defense force) Therefore it is pertinent to note that security knowledge is imparted only through continuous training, correctional measures and trial and error method. Further there is no management theory or school of thought in physical security function that could be taken as a forerunner or principle that had firmly established and rooted in the management evolution. Before the industrialisation during 60s and 70s it was a part of Public administration. There is hardly any separate entity for private security industry actively engaged in the business protection, loss prevention and Risk Management.

3. Basic security training is very essential to any security functionaries in business enterprise.

4. It is related to physical fitness - required for long hours of walking, standing, be awake, alertness, boldness, manage the stress/fatigue. Unlike like any other academic subjects like Science, Maths, English there is no single yardstick to frame the common syllabus for whole of the business world concerning to physical security force.

5. Trained security personnel first understand the basic concept of physical security so that the application of knowledge and practice become easy in the job. Whereas untrained security personnel not only lack in knowledge but also instantly become unsuitable for the realities of the job. 
6. Training and performance go hand in hand and it is dynamic and evolving. Therefore it is imperative that what training does to security personnel performing duties in manufacturing sector will entirely differ from other sectors in the industry.

7. Security function is always co -related with soft skills concepts like discipline, conduct, punctuality, dress, turnout, time bound action, alertness, eye for details, boldness etc. These human concepts do find place in other functions also in the business world. But these are primary areas which are not to be comprised in the security function. Therefore the values of these concepts are taught and reiterated time and again in training which is absent in other management functions.

8. In the event of theft, accident, pilferage etc trained personnel only can address the issues methodically and deduce them to various probabilities of the causes and solutions.

9. The training develops the performance efficiency of the security personnel. They have a direct bearing to protect the people and assets in the business.

10. In short Trained security personnel totally alter the risk and loss prevention areas in the business when untrained security workforce performance is questionable.

\section{The Challenges In SkILling (Training)}

How much to spend for skilling to new workforce and existing workforce?

How much time to invest or spend for skilling?

What are areas for skilling?

What are the training platforms available to train?

Who will be entrusted to skilling them?

Measurement of outcome from skilling

Specific and general outcome expected out of training programme

In current scenario, the training to security personnel during the entry level is the only exposure of job contents/ job description available to the workforce. In most business, the training is simply a formality on records and for the sake of customers requirements. More often not they cadets are trained for a few hours or few days.

The Private Securities Agencies Regulations Act 2005 (PSARA) and Central Association of Private Security Industry (CAPSI) are two regulatory bodies have started playing the active role in meeting the challenges faced in the industry in following areas. The minimum training requirement is 100 hours of class room and 60 hours of field training. The training and certification components have joined together in the industry and it results into the following outcome:

1. Licensing to the qualified business house to start the security business

2. Training to the new workforce

3. Training subjects.

4. Training infrastructure.

5. Accreditation of trainers.

6. Appointing the training agencies and certification.

7. Security audit.

8. License renewal to security business houses.
Some of the following initiatives embarked are in progress in different stages in the industry.

1. Since 2012, Private industries participation with State Govt Initiatives to impart Security training to employable eligible population in industrial belts in States

2. Police Training for private Security requirements through District Police Office to train the youth to provide employment opportunities from 2012.

3. Private Security Organisations Consortium of Training programme to organise training programme in different locations.

One of the foremost challenges faced by the business houses in Private Industrial Security sector is Employability of work force from the point of view of knowledge, application, standards and specific physical fitness expected out of the individuals. Since the knowledge building and application is an ongoing process it requires continuous efforts, time and money on the part of end users employing the security personnel to ensure the security performance at all times.

Stake holders of the change and challenge management include

1. Top Management in the organisation

2. HR department- the implementers

3. Functional Heads in the organization- Functional heads

4. Security Heads - beneficiaries

5. Front line security personnel performing varieties of duties-beneficiaries

From Government sector

1. Secutity sector skill development council (SSSDC)

2. National Skill Development Corporation

Some of the repercussions when challenges are not properly addressed

1. Turn over of Security personnel frequent and some times high in number.

2. Lack of awareness of security knowledge and implications internally.

3. Frequent security lapse or breach in the business premises.

4. Incidents of Fraud, misappropriation of funds, malpractice, willful negligence in work locations, disruption of work, pilferage and connivance.

5. Wrong inputs to the management leading to wrong conclusions.

6. Man hours loss.

7. Negative reputation on Organisations Management practices.

8. Company's Image and good is at stack.

\section{SUGGESTIONS TO OVERCOME THE CHALLENGES}

1. Design a fully committed Security policy with no compromise.

2. Invest in training, knowledge building on security function like any other functions. 
3. Design a written down Policy and Operational manual for security

4. Ensure fair practice and implementation on security guidelines

5. Provide motivating working environment to the security personnel

6. Ensure flow of information is on time and accurate

7. Install the intelligence gathering on security and industrial climate

8. Timely and proper statutory wages with basic welfare measures to security personnel

9. Identify the opportunities for job rotation

10. Make sincere efforts for career growth to security personnel.

11. Supplement the physical security performance with technology where it is beneficial to end users and to the security personnel without compromising the principles.

\section{POSSIBLE OUTCOMES OF CHANGE MANAGEMENT}

1. Minimum security lapse and breach in security affairs

2. Detection of security offence is faster.

3. Better administrative outlook from management point of view

4. Incidents of Loss, fraud, inappropriate dealings are detected and action is initiated.

5. Information flow is timely and more appropriate and accurate

6. Better Industrial intelligence gathering.

7. Employees relationship with external parties will be as per rule book.

8. Potential offenders are weeded out

9. Guilt feeling of punishment to the offenders is less

\section{CONCLUSION}

The security sector is working largely with untrained manpower. From the discussion, it is clear that the Training is the only way to develop the performance of the security personnel in order to prevent the business loss from difficult circumstances. The training infrastructure presently available to the workforce in the country's industrial sectors is hardly sufficient to meet the growing complexities and demands of the industries. The top management should allocate a significant capital to build and maintain the adequate training facilities. On one side the demand for trained security force reflects business growth. On the other side the lack of availability of manpower and the training capacity.

Proper systems and procedures should be in place to hire the trained guards. The industry needs well trained security trainers and knowledge specialists drawn from several fields connected to the different areas of security performance.

There has to be a monitoring system to check, measure and corrective plans as and when required on training scenario. The benefits of security training through change management are immense and they influence the bottom line in the organization when properly managed.

From the Industry and Business angles, much needs to be done. It will take years for the existing manpower to get trained. Training facilities in different locations need to be expanded so as to decentralize the training activities. This will enable the training actions to be carried out with a preplanned Training Calender as followed in other departments.

\section{REFERENCES}

1. Berrong, Stephanie (2009): India's Growing Security Industry, Security Mngt.

2. Parfomak, Paul W. (2004): Guarding America: Security Guard and U.S Critical Infrastructure Protection, Congressional Research Service Report

3. Patel, B.B. (1997) 'Contract Labour India in manufacturing, construction, plantation and forestry', Contract Labour: Looking at issues, Nine Country Cases, ILO

4. Prenzler, Tim, Earle, Karen and Sarre, Rick, (2009): Private Security in Australia: Trends and characteristics, Trends and Issues in Crime and Criminal Justice (June 2009), Australian Institute of Criminology.

5. Plight and Predicament of Security Guards Engaged by Private Security Agencies in India $\square \square$ Dr. Sanjay Upadhyaya, Fellow V.V.Giri National Labour Institute, Noida.

6. International Journal of Management Sciences, ISSN 0973-2101 Vol. 7, No.1, July 2011. 